\title{
Die 'vergroening' van die Christelike godsdiens: Charles Darwin, Pierre Teilhard de Chardin en Lloyd Geering
}

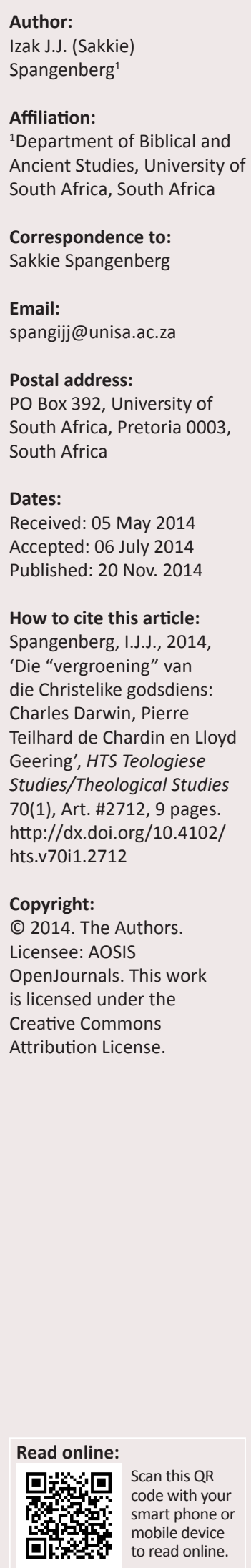

The greening of Christianity: Charles Darwin, Pierre Teilhard de Chardin and Lloyd Geering. Since the time of Charles Darwin, evolutionary biology challenged the metanarrative of Christianity which can be summarised as Fall-Redemption-Judgement. Pierre Teilhard de Chardin tried to circumvent these challenges by integrating the traditional Christian doctrines with evolutionary biology. However, he did not succeed since the Catholic Church, time and again, vetoed his theological publications. A number of Protestant theologians promoted his views but even they could not convince ordinary Christians to accept his views. These were too esoteric for Christians. Most of them were convinced that the acceptance of the theory of evolution will eventually undermine their faith. In recent years Lloyd Geering argued a case for the creation of a new narrative in which the Big Bang and the theory of evolution do play a role. He calls it the 'Greening of Christianity'. This article discusses the metanarrative of Christianity and the challenges the theory of evolution presents before it assesses the views of Pierre Teilhard de Chardin and Lloyd Geering.

The scientific worldview is not about to undergo truly fundamental changes anytime soon. Thus, one can plausibly argue that if religion is to be productively harmonized with science, we must look for a form of religion and theology different from traditional Christian theism. (Grigg 2008:36)

\section{Inleiding}

Dit word tans algemeen aanvaar dat ons 'n ekologiese krisis op die planeet beleef en dat die mensdom hoofsaaklik vir die krisis verantwoordelik is (Caldicott 2009; Gore 2006; Goudie 2013; MacLeod 2013). Daar gaan nie meer 'n jaar verby waarin ons nie van skrikwekkende werwelstorms, verwoestende oorstromings, knellende droogtes, allesvernietigende veldbrande, ongekende sneeuval en die uitsterf van plant- en dierespesies hoor nie. Die meeste van die gebeure hou verband met klimaatsverandering vanweë die hoeveelheid kweekhuisgasse wat die mensdom sedert die Industriële Revolusie (agtiende eeu) in die atmosfeer inblaas (Skinner \& Murck 2011:592-602). 'n Bydraende faktor is die vryemarkstelsel wat voorgehou word as díe ekonomiese stelsel wat groei en vooruitgang vir almal kan verseker. Die groei en vooruitgang geskied dikwels ten koste van die aarde en sy lewensinstandhoudende sisteme. Lynn White (1967) is van mening dat die Christelike godsdiens ten diepste verantwoordelik is vir die ekologiese krisis. Dit verkondig immers dat die mensdom aangestel is om oor alles op aarde te heers en dit te gebruik en verbruik na goeddunke (Gen 1:28).

Hierdie artikel neem die beskuldigings wat aan die adres van die Christelike godsdiens gerig word, ernstig op deur: (1) die Christelike metanarratief of metaverhaal onder die loep te neem; (2) die uitdagings wat die evolusionêre biologie aan hierdie metaverhaal stel, daadwerklik te konfronteer; (2) Pierre Teilhard de Chardin se versoeningspoging te bespreek, en (3) Lloyd Geering se alternatiewe verhaal, wat neerkom op 'n 'vergroening' van die Christelike godsdiens, te beoordeel.

\section{Die Christelike metaverhaal}

Die Oxfordse teoloog, Philip Kennedy, wys in sy boek A modern introduction to theology: New questions for old beliefs (2006) daarop dat die tradisionele Christelike geloof voortvloei uit die teologiese strydgesprekke wat gedurende die vierde en vyfde eeu n.C. in die Romeinse ryk gevoer is. Daar was in daardie stadium verskillende groepe wat verskillende menings gehuldig en op verskillende maniere met Jesus van Nasaret geïdentifiseer het (Fredriksen 2012:67-68; Luttikhuizen 2006). Keiser Konstantyn (275-337) was nie gediend hiermee nie omdat dit sy ideaal van eenheid en vrede in die Romeinse ryk ondergrawe het. Dit was een van die redes waarom hy die Christelike godsdiens tot legitieme godsdiens van die ryk verklaar en 'n vergadering van 
biskoppe in Nicea in 325 n.C. byeengeroep het. Die uitsluitlike doel met die vergadering was om die verskille eens en vir altyd te besleg sodat Christene uit een mond kon praat en daar vrede en voorspoed in die ryk kon heers. Johannes Roldanus (2006:80) verwoord dit só: 'The first ecumenical council of the Church was an invention of the first Christian emperor and it was supposed to come up with his wishes for unity and peace.' Keiser Theodosius die Grote (346-395) het een stap verder gegaan en die Christelike godsdiens tot staatsgodsdiens van die Romeinse ryk verklaar. Aurelius Augustinus (354-430) het op sy beurt 'n stewige teologiese onderbou aan die Christelike godsdiens in hierdie jare voorsien (Kennedy 2006:ix). Dit is aan hom te danke dat Christene steeds aan 'n sondeval glo en vashou aan die oortuiging dat Genesis 2-3 van hierdie 'tragiese gebeurtenis' vertel. Augustinus se teologiese invloed is steeds só sterk dat Kennedy van oortuiging is dat ons van die 'Augustiniaanse paradigma' in die Christelike kerk en teologie kan praat. Hy vat dit saam in drie woorde: 'sondeval-verlossing-eindoordeel' (Kennedy 2006:252). Die Christelike geloof kan ook as 'n metaverhaal omskryf word en hieroor skryf Richard Grigg (2008) die volgende:

Doctrinaire Marxism is (or was) a metanarrative. Religions such as Judaism, Christianity, and Islam offer metanarratives: each purports to tell the whole story of the world and the human project, from creation to divine consummation, and every other sort of human story can purportedly be fit under the umbrella of this religious metanarrative. (bl. 42-43)

Hierdie metaverhaal bevat vyf hoofmomente en kan deur middel van vyf pentagramme voorgestel word (Figuur 1).

Die metaverhaal van die Westerse Christendom begin met die oortuiging dat die Drie-eenheid die ganse kosmos gemaak het (Pentagram 1: Skepping). Hierdie oortuiging

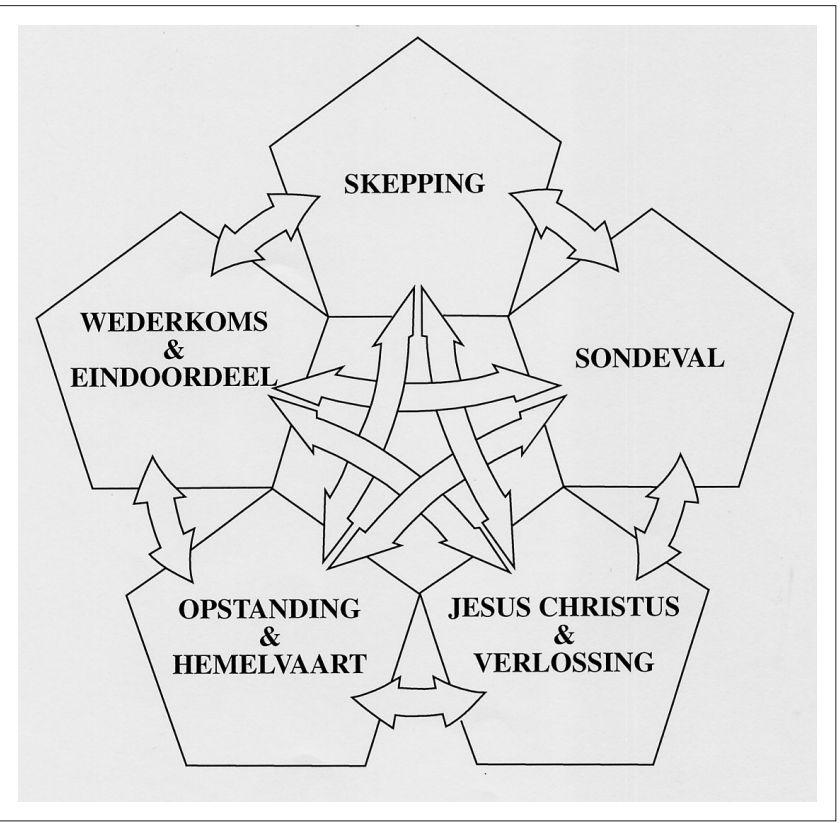

Bron: Spangenberg, I.J.J., 2013, 'Die tradisionele Christelike godsdiens en teologie in die greep van ' $n$ verouderde paradigma: Diagnose en prognose', in LitNet Akademies (Godsdienswetenskappe), besigtig by http://www.litn/et.co.za/Article/die-tradisionelechristelike-godsdiens-en-teologie-in-die-greep-van-n-verouderde-paradigma

FIGUUR 1: Die vyf hoofmomente van die Christelike metaverhaal. Kloksgewys gelees. word hoofsaaklik begrond op die skeppingsverhaal in Genesis 1. Die verhaal vertel hoe God die ganse skepping in ses dae gemaak het. In hierdie kosmos beklee die aarde 'n belangrike plek, want dis die ruimte vir plante, landdiere, visse, voëls en mense. Alles was aanvanklik perfek en doelmatig geskep. God het ook die mensdom geseën en aan hulle die opdrag gegee:

Wees vrugbaar en vermeerder en vul die aarde, onderwerp dit en heers oor die visse van die see en die voëls van die hemel en oor al die diere wat op die aarde kruip. (Gen 1:28)

Maar die skeppingsverhaal stop egter nie daar nie (Spangenberg 2013). Dit word voortgesit in Genesis 2-3. Dáár lees 'n mens hoe die duiwel in die gedaante van 'n slang vir Eva verlei om van die boom in die middel van die tuin te eet. Sy eet daarvan en gee ook aan Adam van hierdie verbode vrugte en só oortree ook hý die verbod (Gen 3:1-6). Deur hul daad van ongehoorsaamheid versteur Adam en Eva nie alleen hul verhouding met God nie, maar ook met die ganse aarde en alles daarop. Dit word duidelik uit die strawwe wat God hulle oplê. Maar dis nie al nie, volgens Augustinus se interpretasie ly die ganse mensdom na dese onder die gevolge van Adam en Eva se ongehoorsaamheid (Fredriksen 2012:112-134; Pagels 1989:129-144; Spangenberg 2009b). Elke kind wat gebore word, is van toe af besmet met die erfsonde. Hulle word almal 'in sonde ontvang en gebore en leef onder God se toorn' (die woorde van 'n ou gereformeerde doopformulier). Ons kry hier met die tweede kernwaarheid van die metaverhaal te doen: die sondeval (Pentagram 2: Sondeval). Die sondeval kan egter slegs in samehang met die idee van'n goeie en perfekte skepping (Pentagram 1: Skepping) verstaan word - vandaar die verbindingspyle tussen die eerste twee momente van die metaverhaal.

Die sondeval van Adam en Eva, wat hulle en hul nageslag se verhouding met God versteur en daartoe gelei het dat alle mense sterf, word egter deur Jesus Christus se kruisdood en opstanding opgehef (Spangenberg 2009b; Spangenberg 2013). Jesus Christus dra met sy kruisdood die straf wat alle mense toekom. Hý sterf namens die ganse mensdom en in hul plek onder God die Vader se toorn (Pentagram 3: Jesus Christus $\mathcal{E}$ Verlossing). Hy verlos hulle en versoen hulle weer met God. Só word die breuk geheel wat tussen Hom en die mensdom ontstaan het. Jesus se verlossing (Pentagram 3: Jesus Christus $\mathcal{E}$ Verlossing) kan op sy beurt slegs in samehang met die sondeval (Pentagram 2: Sondeval) verstaan word - vandaar die verbindingspyle tussen die tweede en derde momente van die metaverhaal.

Maar Jesus sterf nie net aan die kruis nie - Hy oorwin ook die dood deurdat Hy uit die graf opstaan, op aarde rondwandel en uiteindelik terugkeer na die hemel (Pentagram 4: Opstanding $\mathcal{E}$ Hemelvaart). Die opstanding word beskou as die eerste teken (bloeisel) van die nuwe skepping. Dit verkondig: 'God se somer kom!' Die kerk is nie net die draer van hierdie boodskap nie, maar is self ook 'n teken daarvan. In die woorde van Flip Theron (1978):

Soos die lentebloeisels die vrug is van die stuwende krag van die somer, so kondig God se op hande synde somer hom reeds werksaam teenwoordig aan in die teken [van die kerk]. (bl. 96) 
Jesus se kruisiging, opstanding en hemelvaart is egter een samehangende verlossingsgebeurtenis. Jesus sterf nie net onder God die Vader se toorn nie (Pentagram 3: Jesus Christus $\mathcal{E}$ Verlossing), maar hy word ook opgewek uit die dood (Pentagram 4: Opstanding E Hemelvaart). Die opstanding en hemelvaart is die teken dat die verlossing suksesvol was en daarom is daar ook verbindingspyle tussen die derde en vierde momente van die metaverhaal.

Die skepping sal egter eers finaal herstel word wanneer Jesus Christus na hierdie aarde terugkeer om die skepping te vernuwe en alle mense te oordeel (Pentagram 5: Wederkoms $\mathcal{E}$ Eindoordeel). Diegene wat sy oorwinning en verlossing nie aanvaar het nie, sal die ewige straf in die hel tegemoet gaan. Diegene wat egter die verlossing aanvaar het, sal die nuwe Jerusalem bewoon wat vanuit die hemel na die nuwe aarde neerdaal (Op 21). Daarmee is ons terug by Pentagram 1: Skepping - maar nou die herstelde skepping! In hierdie geval val skepping en herskepping dus saam.

Die verbindingspyle in die middel van die diagram, asook tussen die vyf individuele pentagramme (soos in sommige gevalle reeds uitgewys) toon hoe ineengevleg die verskillende momente en waarhede van die metaverhaal is. Dit hou in dat enige versteuring van één van die waarhede 'n versteuring van die totale metaverhaal tot gevolg sal hê. Diegene wat dus die sondeval (en die dood as straf op sonde) ontken, bring nie net Jesus Christus se kruisdood en opstanding in die gedrang nie, maar ook die wederkoms en eindoordeel - en die idee van 'n nuwe skepping (Spangenberg 2013). Volgens James Barr (1977) speel sonde en verlossing slegs by konserwatiewe evangeliese Christelike groepe hierdie oorheersende rol:

Sin is so powerful and so bad that conservative evangelicalism is the only faith that faces up to its awfulness. Sin is the reason why we have a Jesus Christ, why we have a substitutionary atonement, why we have a Holy Spirit, why we need a second advent. Sin is a valuable intellectual resource to this form of religion: without it, it could not get anywhere. (bl. 177)

Na my mening oordeel Barr hier verkeerd. Die sondeval en sonde speel in al die Christelike kerke in die hoofstroom hierdie allesomvattende rol in hul teologie, missiologie en liturgie. Sonder die idee van 'n sondeval, maak die metaverhaal (en dus die Christelike godsdiens) geen sin nie. Kennedy (2006) vat die saak korrek saam wanneer hy skryf:

In sum, the three pillars of Christianity's conventional account of human destiny in relation to God are the doctrines of humanity's Fall, engineered by Adam and Eve; Redemption wrought by the self-sacrificing death of Jesus Christ; and his future Judgement of the entire human race. The entire lattice of traditional Christian doctrine can be condensed into a slogan of two words: 'Jesus saves'. (bl. ix)

Waarvan red Jesus Christus die mensdom anders as van die sondeval en sy gevolge, naamlik vervreemding en dood?

Uit die bostaande behoort dit duidelik te wees dat die tradisionele Christelike godsdiens en teologie deur en deur mensgesentreerd is (Spangenberg 2007). Dit fokus uitsluitlik op die mensdom en hul heil, voorspoed en geluk. Die aarde met sy rykdom aan plante, diere, voëls, visse en insekte kom eintlik nie in die visier nie. Dit reflekteer verder geen besorgdheid oor die welsyn van die aarde en alles daarop nie (Spangenberg 2013). Maar dis nie al nie - die ekumeniese belydenisse weerspieël dat die Christelike geloof verweef is deur die antieke drieverdieping-heelal (Kennedy 2006:222224). Jesus Christus kom immers uit die boonste verdieping (hemel) en word op aarde gebore (middelvlak) waar Hy ly, sterf en neerdaal na die onderwêreld (keldervlak/hel) voordat Hy weer terugkeer na die boonste verdieping (hemel) om daar aan God die Vader se regterhand te sit en wag op die aanbreek van die eindtyd.

Daar is hoofsaaklik drie redes waarom die tradisionele Christelike geloof moeilik te rym is met die meer onlangse wetenskaplike kennis en waarom dit nie 'n goeie gespreksgenoot in die gesprekke oor die ekologiese krisis kan wees nie. Eerstens werk dit met 'n uitgediende wêreldbeeld wat net weet van 'n hemel, 'n aarde en 'n onderwêreld. Tweedens hou dit vas aan 'n uitgediende mensbeskouing wat die mens tegelykertyd as kroon van die skepping, maar ook as gevalle sondaar beskou wat vir die hemel gered moet word. Derdens hang dit 'n uitgediende siening aan van hoe die aarde en lewe daarop ontstaan het.

In die volgende afdeling sal die uitdagings wat die evolusieleer aan die tradisionele Christelike godsdiens stel, verder uitgespel word. Dit word gedoen ter motivering van die standpunt dat teoloë ' $n$ ander verhaal sal moet ontwikkel ten einde sinvol aan die gesprekke oor die ekologiese krisis te kan deelneem. ${ }^{1}$

\section{Charles Darwin (1809-1882)}

Charles Darwin (1809-1882) word soms die Nikolas Kopernikus (1473-1543) van die biologiese wetenskappe genoem. Die rede? Die omwenteling wat Darwin in die biologiese wetenskappe teweeggebring het, is vergelykbaar met die omwenteling wat Kopernikus in die sterrekunde teweeggebring het (Stewart-Williams 2010:11-12). Beide hierdie geleerdes het Westerlinge se sienings van hulself en hul wêreld radikaal verander (Stewart-Williams 2010:166). Hul teorieë het egter ook die verstaan van die Bybel en die metaverhaal van die Christelike geloof uitgedaag. Terwyl die Christelike kerke Kopernikus se teorie dat die aarde om die son draai al aanvaar het, sukkel hulle nog om die evolusieteorie te aanvaar. Die rede waarom teoloë en gelowiges weerstand bied, hang onder andere saam met die drie sake wat hierbo genoem is, maar daar is ook ander sake wat aandag verdien (Spangenberg 2013, 2014).

Tydens Darwin se leeftyd het die deursnee-Westerling geglo dat die aarde in 4004 v.C. geskep is; voorts, dat al die plant-

1. Heelwat Afrikaanssprekende teoloë en Bybelwetenskaplikes het al publikasies oor die Christelike geloof en die ekologiese krisis geskryf, maar deur die bank neem hulle die Christelike metanarratief as vertrekpunt. Neem die publikasies neem hulle die Christelike metanarratief as vertrekpunt. Neem die publikasies van Ernst Conradie (2011, 2013) as voorbeeld. Die Christelike metanarratie vorm die vertekpunt van al sy publikasies (vgl. slegs Conradie 2006:178). Hiermee systap hy grootliks die huidige wetenskaplike kennis oor die ontstaan van die aarde en lewe op aarde. Hy reageer nie op die wete dat daar ook vroeer uitwissings op aarde was nie en bespreek nie hoe die sesde groot uitwissing van lewe op aarde van die voriges verskil nie. Die skrywer van hierdie artike beplan om in ' $n$ volgende artikel die publikasies van Suid-Afrikaanse teoloë oor die ekologiese krisis onder die loep te neem. 
en dierespesies waarvan hulle geweet het, oorspronklik só deur God geskep is. Die idee dat die aarde in 4004 v.C. geskep is, het hulle van die Ierse biskop James Ussher (1581-1656) gekry. Hy het die geslagsregisters in die Bybel noukeurig bestudeer en allerlei wiskundige berekeninge gedoen voordat hy hierdie siening van hom bekend gemaak het (Barr 2013:375-397). Dit het só waar en betroubaar gelyk dat hierdie datum sedert 1701 in die Authorized Version (ook bekend as die King James Version) van die Bybel opgeneem is (Spangenberg 2013, 2014).

Die siening dat alle bestaande plant- en dierespesies oorspronklik só deur God geskep is, het mense voor Darwin se leeftyd as 't ware met moedersmelk ingekry: 'In the era after Aristotle and before Darwin, the fixity of species was a core belief' (Primavesi 2000:39). Afgesien van hierdie idee was daar ook die idee dat daar ' $n$ vaste rangorde in die skepping bestaan. Mense het gepraat van 'the Great Chain of Being'. Net soos daar verskillende sporte op 'n leer is, so is daar verskillende 'sporte' in die skepping. God sit aan die top en benede Hom volg die engele, mense, diere, plante en dan lewelose dinge (Mosley \& Lynch 2010:106; Weinert 2009:98-99). Die idee van perfeksie hou ook hiermee verband. Visse het vinne en kiewe want hulle is perfek gemaak vir die omgewing waarin hulle moet leef en oorleef. Voëls is met vlerke en vere geskep sodat hulle in die hemelruim kan vlieg. Hulle is perfek gemaak vir die omgewing waarin hulle moet leef en oorleef. Dit geld vir elke ander plant- en dierespesie op aarde, asook van die mens (Spangenberg 2013, 2014).

Hierdieidee van ordeen rangordeen ewige onveranderlikheid is selfs in geestelike liedere uitgedruk. Vergelyk byvoorbeeld die lied All things bright and beautiful wat deur Cecile Frances Alexander (1823-1895) geskryf is en waarvan 'n gedeelte soos volg lui (Spangeberg 2013, 2014; Thomson 2005:244):

The rich man in his castle

The poor man at his gate

God made them, high and lowly,

And ordered their estates.

Daar is nie toevallig ryk en arm mense in 'n samelewing nie. God wys aan elke mens ' $n$ vaste plek in die samelewing toe. As jy as 'n slaaf gebore is, moet jy vir lief neem daarmee. As jy tot die adelstand behoort en ryk is, is dit aan God te danke. Hierdie idee het mense uit die Bybel afgelees en hulle, onder andere, op Genesis 1 daarvoor beroep. God het alles in ses dae geskep en dis duidelik dat daar 'n rangorde in die skepping bestaan. Die skeppingsverhaal begin immers eers met die skep van die aarde voordat die plante geskep word. Na die plante volg visse en ander waterdiere. Dit word weer opgevolg met die skep van landdiere voordat die mens aan die beurt kom. Net van die mens word gesê dat hy die beelddraer van God is (Gen 1:27). Voorts word die mens as die kroon van die skepping gesien - hy is so te sê 'n goddelike wese (Ps 8:6) (Spangenberg 2013, 2014).

Darwin se teorie van evolusie langs die weg van natuurlike seleksie het hierdie sienings uitgedaag (Spangenberg 2009a; Weinert 2009:93-106, 112-124). Hy het eerstens die standpunt van die geoloog Charles Lyell (1797-1875) aanvaar dat die aarde baie oud is. Tweedens het hy afskeid geneem van die idee dat plant- en dierespesies ewig en onveranderlik is. Derdens het hy die idee van lineêre en progressiewe evolusie verwerp. Sy siening kan as vertakkende evolusie ('branching evolution') voorgehou word. Vierdens het hy die idee dat die mens die eindpunt van lineêre en progressiewe evolusie is, nek omgedraai. Laastens het hy afskeid geneem van die idee van ontwerp ('design'). Dit is dus te verstane dat biskop Samuel Wilberforce (1805-1873) hom verplig gevoel het om Darwin se teorie van evolusie langs die weg van natuurlike seleksie, teen te staan. Sedertdien het verskeie ander teoloë en gelowiges hulle by Wilberforce aangesluit en teruggegryp na die sienings van die teoloog William Paley (1743-1805). Hy het in sy boek Natural theology die siening voorgestaan dat die natuur na regte 'n Skeppergod veronderstel. Alles is so mooi en perfek geskape dat dit onmoontlik is om te ontken dat daar 'n Skeppergod is. Darwin moes hierdie boek tydens sy studiejare as teologiestudent aan die Universiteit van Cambridge bestudeer en was aanvanklik baie beïndruk met Paley se argumente, maar hy het later daarvan afskeid geneem (Spangenberg 2013, 2014; Thomson 2005:259-265).

Die evolusieteorie soos Darwin dit bedink en in sy boeke The origin of species by means of natural selection (1859) en The descent of man (1871) beskryf het (vgl. Darwin 1952), het hom oor die afgelope meer as 150 jaar as betroubaar bewys (Ayala 2006; Asher 2012:38-41; Morvillo 2010:185210). Baie Christene sukkel steeds om daarmee vrede te maak. Hulle sal soms 'n hoër ouderdom vir die aarde aanvaar, maar die konsekwensies wat die evolusieteorie vir die Christelike metaverhaal inhou, ignoreer of systap (Spangenberg 2013, 2014). Neem slegs die volgende as voorbeelde (Spangenberg 2009a):

- Die Christelike metaverhaal verkondig dat daar vroeg in die geskiedenis van die skepping 'n Adam en Eva bestaan het wie se wandaad tot 'n sondeval en die dood gelei het. (Dood hang egter nie saam met 'n sondeval nie, want heelwat vroeëre spesies het gesterf - selfs nog voordat daar mense op aarde was [Eloff 1975:15].)

- Die mens het 'n Verlosser nodig wat onaangetas deur die erfsonde moes wees. Slegs só 'n Verlosser kan die bose kringloop wat die sondeval in die skepping ingedra het, omkeer. (Daar bestaan nie so 'n kringloop nie. Dis 'n teologiese konstruksie van Augustinus wat met sy eie seksuele drifte nie kon vrede maak nie [DeConick 2013:121-128; Fredriksen 2012:121-122].)

- Die tradisionele Christelike geloof aanvaar dat slegs mense na God se beeld geskep en gevolglik die kroon van die skepping is. (Maar, kan 'n mens vra, hoe kan slegs húlle beelddraers wees as hulle uit ander lewensvorme geëvolueer het? Voorts, hoe kan hulle die kroon van die skepping wees as daar nie lineêre en progressiewe evolusie bestaan nie, maar slegs vertakkende evolusie [Ryke 1987:154-170]?)

Dat die evolusieleer ernstige gevolge vir die tradisionele Christelike metaverhaal inhou, kan nie ontken word nie (Degenaar 1965:47-49; Stewart-Williams 2010). Tog was en 
is daar heelwat wetenskaplikes wat die evolusieleer volledig aanvaar en steeds aan die tradisionele Christelike geloof bly vashou. Een so 'n persoon was Pierre Teilhard de Chardin. Sy poging om die evolusieleer met die Christelike geloof te versoen, word soms hoog aangeprys. Die onlangse publikasie van Jaap Durand (2013) is een voorbeeld hiervan en dit word in die volgende afdeling kortliks bespreek.

\section{Pierre Teilhard de Chardin (1881-1955)}

Pierre Teilhard de Chardin (1881-1955) was 'n RoomsKatolieke priester in die orde van die Jesuïete en het hom in der mate ingegrawe in die geologie en paleontologie dat sy vakgenote hom as ' $n$ briljante kenner en navorser erken het. Hy het die wêreld deurkruis en het navorsing gedoen in Frankryk, Brittanje, China, die Verenigde State van Amerika (VSA) en selfs ook in Suid-Afrika. Hy het Suid-Afrika twee keer besoek en wel in 1951 en 1953. Die uitnodiging om SuidAfrika te besoek, het direk van Jan Smuts gekom - iemand wat al in sy dae gereken het dat die wieg van die mensdom moontlik in Suid-Afrika geleë was (Durand 2013:196-197). Hier het hy besoek gebring aan, onder andere, Sterkfontein, Swartkrans, Makapansgatvallei en Taung. Hy het tydens een van hierdie besoeke 'n lesing voor die Geologiese Vereniging van Suid-Afrika gelewer en daarin gemeld dat sy besoek aan Suid-Afrika hom oortuig het dat die oorsprong van die mens eerder in Afrika as in Asië gesoek moet word (Degenaar 1965:3; Durand 2013:233). Hy was, onder andere, beïndruk deur die groot hoeveelheid en variasie van antieke klipwerktuie wat hier te vind is.

Teilhard het sy wetenskaplike kennis probeer integreer met die Christelike dogmas en verskeie teologiese manuskripte geskryf waarin hy sy sienings verwoord het, maar die Jesuïete-orde en die Rooms-Katolieke sensuurstelsel het dit as gevaarlike kettery beoordeel (Degenaar 1965:3). Van sy teologiese manuskripte is daarom eers nadoods gepubliseer. Dit sluit die boeke Le phénomène humain (Die verskynsel mens) en Le milieu divin (Die goddelike milieu) in - respektiewelik gepubliseer in 1955 en 1960.

Volgens sy oortuiging verloop evolusie van eenvoudige lewensvorme na meer komplekse lewensvorme. Hierdie proses mond uiteindelik uit in die mens, met sy bewussyn wat nie net al die kompleksiteite van evolusie verstaan nie, maar ook oor die sin en betekenis van die lewe self kan nadink (Degenaar 1965:22-24). Alhoewel die mensspesie homo sapiens ingebed is in die evolusionêre prosesse, is daar by hierdie spesie heelwat meer te vind as by ander soogdiere en ander lewensvorme. Mense bring 'n nuwe dimensie op aarde deurdat hulle met hul denkprosesse 'n noösfeer skep (Degenaar 1965:19-20; Durand 2013:191, 241; Geering 2013:77-90). Die noösfeer is 'n spirituele sfeer geleë tussen die biosfeer en 'punt Omega'. Daar is sedert die verskyning van homo sapiens ' $n$ 'denklaag' op aarde - iets soortgelyks aan die neokorteks in die menslike brein. Lloyd Geering (2013) verwoord dit soos volg:
Just as Earth had become enveloped by the hydrosphere, the atmosphere and the biosphere in turn, Teilhard saw the evolution of thought within the human species as a significant new activity encompassing Earth, which he said now possessed a 'thinking envelope'. (bl. 86)

Volgens Teilhard is die noösfeer die beginpunt van 'n nuwe ontwikkeling in die evolusionêre proses. Durand (2013) stel dit só:

Soos die eerste organismes na hoër vorme getas het, so tas die mens in die noösfeer na groter vorme van organisasie in sy bewussyn. Die mens neem nou doelbewus aan sy eie evolusie deel. Langs hierdie weg word die mens méér mens. Teilhard noem dit die proses van 'hominisasie'. (bl. 303)

Jesus Christus is verder vir Teilhard ' $n$ illustrasie van die doel waarop evolusie afstuur. Alles word uiteindelik opgeneem in God, ofte wel 'punt Omega', soos hy dit verwoord. In Durand (2013:190) se woorde: 'Die aarde ontvou en bars oop in die rigting van God, terwyl God sy wortels na onder in die aarde instoot om dit van onder te voed.' Op 'n ander plek verwoord Durand dit só: 'Die evolusie van die wêreld en die menslike gees is georiënteer aan 'n eindpunt, die ultrakritiese rypingspunt, die spits van die evolusiekegel - Teilhard se beroemd geworde punt Omega' (Durand 2013:305-306). Dis duidelik dat Teilhard met sy idee van 'n stygende lyn in die evolusie van lewensvorme, afwyk van Darwin se idee van vertakkende evolusie (Degenaar 1965:50).

Durand (2013:110) erken dat Pierre Teilhard 'n 'hoogs spekulatiewe denksisteem' nagelaat het, maar uit sy bespreking blyk dit dat hy groot waardering vir hom het. Hy stel dit soos volg: 'Teilhard het die wapen uit die hande van materialiste geneem en dit teen hulle gedraai met ' $n$ teorie oor die heelal wat tegelykertyd evolusionêr en kompromisloos geestelik is' (Durand 2013:210). Hy het die natuurwetenskap nie uitsluitlik in die hande van wetenskaplikes gelaat nie, maar hulle gedwing om ook oor die geestelike sy van die lewe en die evolusionêre proses na te dink. Geen geoloog of paleontoloog het, na my wete, Teilhard op hierdie denkweg gevolg nie. Die rede daarvoor is dat hy 'n hipotese voorgedra het wat op geen manier wetenskaplik toetsbaar is nie. Teilhard se hipotese het wel heelwat aandag getrek, maar dit raak nog kant nog wal as wetenskaplike verklaring. Buitendien, waarom hou die evolusionêre prosesse op aarde met die Christelike geloof verband en nie met dié van Islam of die Judaïsme nie? Waarom is die Christelike God die 'punt Omega'? Hierdie vrae is 'n bewys dat Teilhard nog vasgevang was in die ideologie van Christelike absolutisme: naas die Christelike godsdiens is daar geen ander godsdiens wat die waarheid aangaande God, mens en die kosmos korrek kon verwoord nie.

'n Tweede punt van kritiek is dat Teilhard die kennis wat hy oor die geologie en paleontologie opgedoen het, nie ook op die Christelike geloof van toepassing gemaak het nie. Daar was net eenrigtingverkeer in sy denke: Hy wou die evolusieleer 'Christifiseer' (Durand 2013:260), maar het nie vir één oomblik daaraan gedink dat die Christelike godsdiens self ook geëvolueer het nie (Spangenberg 2009c). Enige 
geologiestudent weet dat tyd niks onveranderd laat nie. Dit geld natuurlik ook vir die mens en sy kultuurprodukte. Argeologiese studies bevestig dit. Dis vreemd dat Teilhard hierdie insig nie op die ontstaan en ontwikkeling van die Christelike godsdiens oorgedra het nie. Daar is 'n soort blinde kol by hom aanwesig deurdat hy nie besef dat die godsdiens waarin hy gesosialiseer is ook die vingermerke van die tyd dra nie. Die Christelike geloof bestaan nie van alle ewigheid af nie - so ook nie die idee van 'n sondeval, 'n Drie-eenheid of 'n wederkoms en eindoordeel nie. Hierdie godsdiens en sy dogmas het binne die bestek van tyd ontwikkel en gegroei.

'n Derde punt van kritiek is dat Teilhard geensins kennis geneem het van die ontwikkelinge op die terrein van die Bybelwetenskappe gedurende sy leeftyd nie. Die Bybelwetenskappe het gedurende die laaste jare van die negentiende en die beginjare van die twintigste eeu 'n paradigmaverandering beleef (Noll 1991:45; Spangenberg 1994:145-156). Die Bybel is nie meer beskou as 'n bowe historiese, goddelik geïnspireerde boek waarin finale waarhede oor God, die mens en die skepping opgeteken is nie. Bybelwetenskaplikes het begin om die Bybel soos 'n gewone boek te bestudeer en met allerlei nuwe hipoteses oor die oorsprong van sekere dele daarvan na vore gekom. Kort voor lank was daar 'n paar hipoteses oor die ontstaan van die Pentateug op tafel. Moses is nie meer aanvaar as die enigste skrywer van die ganse Pentateug nie. Dit geld ook van die Sinoptiese evangelies: Matteus, Markus en Lukas. NuweTestamentici het nie meer aanvaar dat dit die orde is waarin die evangelies geskryf is nie. Volgens die meerderheid is Markus eerste geskryf en het die skrywers van die Matteusen Lukasevangelie groot dele daarvan oorgeneem. Maar dis nie al nie. Hulle het ook van 'n tweede bron gebruik gemaak om hul evangelies saam te stel: die sogenaamde Q-bron. Hierdie bron is uit die ooreenstemmende dele in die Matteusen Lukasevangelie saamgestel. Dié paradigmaverandering het aanvanklik net binne die geledere van Protestantse Bybelwetenskaplikes voorgekom, maar daar is reeds enkele Rooms-Katolieke teoloë wat kennis geneem het van die meer onlangse verwikkelinge. Een van hulle was Alfred Firmin Loisy (1857-1940), 'n tydgenoot van Teilhard. Hy word beskou as die vader van die moderne Bybelwetenskaplike navorsing in die Rooms-Katolieke Kerk en het 'n beroering veroorsaak met sy standpunt dat die Bybel nie absolute waarhede bevat nie. Die Bybel is deur mense met beperkte kennis en insig geskryf, het hy geargumenteer. Hulle kon nie absolute waarhede oor God formuleer nie:

God is before everything else a mystery that transcends us. And to claim to express in human language the last word about him is, in effect, to blaspheme him ... Absolute truth is not revealed. (vgl. Beeson 1999:2)

Nodeloos om te sê dat Loisy sy rieme styf geloop het met sensuurgesag van die Rooms-Katolieke Kerk. Hy is in 1908 geëkskommunikeer. Teilhard het hom, anders as Loisy, nie teen die Rooms-Katolieke leergesag verset nie. Dis eintlik verstommend wanneer 'n mens lees hoe gedweë hy sekere besluite oor hom en sy manuskripte aanvaar het.
Vanuit Pierre Teilhard de Chardin se lewe en publikasies kom die belangrike les dat teoloë nie meer hul vak kan beoefen sonder om kennis te neem van wat op ander wetenskaplike terreine gebeur nie. Teoloë en predikante kan nie maar net voortgaan en kerklike dogmas verkondig asof mense in die antieke wêreld leef nie (Kennedy 2006:219-238). Voorts staan dit soos 'n paal bo water dat lewe op aarde langs die weg van evolusie ontplooi het (Morvillo 2010; Park 2012; Silvertown 2008). Teilhard het dit heelhartig aanvaar en deelgeneem aan die soektog na fossiele wat die evolusiegeskiedenis van die mens weerspieël. Hy het wel probeer om in die RoomsKatolieke Kerk se goeie boekies te bly en sy kennis van die geologie en paleontologie met kerklike leerstukke probeer rym. Sy poging tot versoening is egter nie bevredigend nie. Wie die evolusieleer aanvaar, kan nie terugdeins van die konsekwensies wat dit vir die tradisionele Christelike leerstellings inhou nie (Degenaar 1965:47-49). Dit sluit in afskeid neem van die idee van 'n Skeppergod wat alles wat bestaan, presies só aan die begin van die skepping gemaak het; 'n sondeval en die oortuiging dat die dood straf weens oervoorouers se ongehoorsaamheid is. Ook van die idee van 'n Verlossergod wat die mensdom aan die einde van die tyd finaal van die dood gaan bevry. Dood, so weet ons vandag, is deel van hoe lewe op aarde funksioneer. Dis ook hoe die ganse kosmos funksioneer. Net soos mense gebore word en sterf, so word ook sterre en sterrestelsels gebore en sterf hulle (Gribbin 2000). 'n Aanvaarding van die evolusieleer hou ook in dat ' $n$ mens afskeid moet neem van die idee dat mense siele het, dat hulle die kroon van die skepping is en dat alles op aarde om mense en hul heil en voorspoed draai (Primavesi 2000). Mense is 'n vertakking van die 'boom van lewe' en daarby slegs maar 'n onlangse vertakking. Dit is wel so dat die mensdom sedert die Industriële Revolusie 'n geweldige impak op die aarde en alles daarop het. Hieroor is daar nie meer te kibbel nie - wel oor die soort teologie wat hiertoe ' $n$ bydrae gelewer het en of Christene 'n nuwe verhaal kan ontwikkel ten einde mense te motiveer om met groter verantwoordelikheid te leef.

\section{Lloyd Geering (1918-)}

Lloyd Geering word dikwels die Don Cupitt van NieuSeeland genoem. Net soos Cupitt van Brittanje (Cupitt 2001, 2006, 2008), beywer hy hom vir vernuwing van die Christelike geloof en publiseer hy gereeld boeke oor die onderwerp (Geering 2002, 2005, 2009, 2013). Hy het bekendheid verwerf deur reeds in die sestigerjare van die vorige eeu te argumenteer dat Jesus nie histories en letterlik uit die dood opgestaan het nie. Hy is van kettery aangekla, maar die Presbiteriaanse kerk van Nieu-Seeland het hom onskuldig bevind (Geering 2007:131-164; Spangenberg 2011). Sedert die eeuwending skryf hy gereeld oor die Christelike geloof en die ekologiese krisis en lewer hy 'n pleidooi vir 'vergroening' van die Christelike godsdiens. Hy vind veral aanklank by die oortuiging van James Lovelock dat die aarde 'n sisteem is waarvan die verskillende subsisteme meewerk om lewe op hierdie planeet in stand te hou (Lovelock 1995). Dit is daarom nie vreemd nie dat een van sy onlangse boeke die titel dra Coming back to Earth: From gods, to God, to Gaia 
(Geering 2009). Sy argumente sal menige konserwatiewe teoloog en kerklidmaat ontstig, want hy draai nie doekies om wanneer hy sy standpunt stel nie. Hy is deeglik onderlê in die navorsing rondom die Bybelwetenskappe en is op hoogte van die standpunte van tydgenootlike teoloë. Wat die Bybelwetenskappe betref, aanvaar hy die standpunt dat die Bybel 'n doodgewone, menslike boek is en wat die kerk en sy teologie betref, geld dit eweneens dat dit mensgemaak is. Die volgende stellings is van kardinale belang, as 'n mens hom en sy standpunt oor die 'vergroening' van die Christelike godsdiens goed wil begryp:

There is great reluctance in the church, even amongst many of its biblical and theological scholars, to concede that the Bible is just as human in origin and content as any other book, and that the church, far from being a supernatural society of divine origin, shows itself to be all too human. The church's claim to be a unique channel for divine revelation and, hence, in possession of a unique body of revealed truth, has set it on a collision path with other claimants to truth, such as the whole scientific enterprise, modern historiography and other religious traditions. (Geering 2001:83)

Hiermee saam moet 'n mens ook kennis neem van sy oortuiging dat die mensdom reeds 'n tweede aksiale periode betree het. Die Duitse filosoof Karl Jaspers (18831969) het die idee van 'n aksiale periode in die geskiedenis van die mensdom die eerste keer geformuleer. Volgens hom het daar gedurende die periode $800-200$ v.C. belangrike figure geleef wat die mensdom se denke en oortuigings ingrypend beïnvloed het. Dit was die periode waartydens die groot profete van Israel, asook verskeie ander groot geeste soos Zoroaster, Confucius, Boeddha, die Griekse filosowe en nog vele ander geleef het. Volgens Geering (2009:3) het die tweede aksiale periode tussen 1400-1900 in die Weste voorgekom, en die Verligting verteenwoordig 'n drempel wat oorgesteek is en waarheen nooit weer teruggekeer kan word nie. Westerlinge kan eenvoudig nie meer die naïewiteit van voor die Verligting openbaar nie en daarom moet hulle van 'n hele klomp uitgediende kerklike leerstellings ontslae raak:

The Second Axial Period requires us to jettison a great deal more than the Protestant Reformers did - including a post-mortem heaven and hell, a divine savior, an objective personal deity, the doctrine of the atonement, and the whole system of dogma that envelops them. (Geering 2009:74)

Op grond van die voorafgaande stellings is dit verstaanbaar dat Geering aanklank gevind het by die Sea of Faith Movement in Brittanje en by die Jesus Seminar in die VSA (Geering 2007:212-228). Volgens sy oortuiging moet die Christelike godsdiens 'n radikale verandering ondergaan. Dit moet 'n godsdiens word waarin afskeid geneem word van die tradisionele verstaan van God as 'n teïstiese wese wat buite ons kosmos êrens in die hemelruim leef. Binne hierdie hersiene Christelike godsdiens moet daar egter steeds ruimte bestaan vir Jesus, die Joodse profeet en wysheidsleermeester, wat aan die begin van ons jaartelling in Palestina geleef en gepreek het (Geering 2002:145). Christene moet egter die oerknal- en die evolusieteorie aanvaar, want alleen só kan hulle 'n sinvolle bydrae tot die gesprekke oor die ekologiese krisis lewer. In sy mees onlangse boek (Geering 2013) neem hy lesers deur die verskillende stadia van die ontwikkeling van die kosmos, die aarde, lewe op aarde en die uiteindelik evoluering van die mens wat in staat is om alles te kan verstaan en daaroor te kan nadink.

In 'n vroeëre boek wys hy op die tragiese ironie dat terwyl fundamentalistiese Christene tans hamer op 'n wederkoms met sy katastrofiese gevolge vir die aarde, ander Christene intens bewus geraak het van die ekologiese krisis waarmee die ganse planeet gekonfronteer word, en dan maak hy hierdie veelseggende opmerking:

Since the great majority of Christian fundamentalists live in the United States, it is no accident that this most powerful nation not only rejects such international protocols as the Kyoto agreement, but undertakes actions that directly endanger world peace. (Geering 2005:15)

Diegene wat 'n pleidooi lewer vir die vergroening van die Christelike godsdiens kom dus te staan voor geweldige teenstand vanuit fundamentalistiese kringe. Dis moeilik om laasgenoemdes te oortuig dat die Christelike godsdiens vanuit Judaïsme in die eerste eeu ontwikkel het en dat dit in die vierde en vyfde eeu radikale veranderinge ondergaan het toe dit staatsgodsdiens van die Romeinse ryk geword het. Westerlinge se meerderwaardigheid en hul neerkyk op ander beskawings, kulture en mense hou direk hiermee verband. Christene sal van hierdie meerderwaardigheid afskeid moet neem en moet aanvaar dat ander godsdienste, beskawings en kulture ook op waarheid aanspraak kan maak.

\section{Slotopmerkings}

Uit die voorafgaande behoort dit duidelik te wees dat die Christelike godsdiens 'n radikale verandering sal moet ondergaan as dit sinvol aan die gesprekke oor die ekologiese krisis wil deelneem en mense wil oortuig dat hulle hul lewenswyses moet verander ten einde lewe op aarde te bewaar. 'n Nuwe verhaal moet dus ontwikkel word en daardie verhaal sal die meer onlangse wetenskaplike kennis moet verdiskonteer. $\mathrm{Na}$ my mening sal die nuwe verhaal moet begin deur aan Christene te verduidelik dat die Bybelse skeppingsverhaal nie meer as vertrekpunt geneem kan word vir hul besinning oor die skepping en die mens nie. Daar was geen sondeval aan die begin van die skepping nie en dood is nie ' $n$ straf op sonde nie. Alle lewende dinge op aarde word gebore, groei en sterf. Die totale kosmos opereer op hierdie patroon: sterre word gebore, groei en sterf; planete word gebore, groei en sterf; sterrestelsels word gebore, groei en sterf (Gribbin 2000). In hierdie proses word materie weer gehersirkuleer en ontstaan nuwe dinge uit die voriges. Die oerknal- en die evolusieteorie sal op 'n eenvoudige manier aan alle Christene verduidelik moet word sodat hulle daarmee vrede kan maak en dit hul eie kan maak.

Wanneer afskeid geneem word van die tradisionele verstaan van Genesis 1-3, sal mense ook ingelig moet word dat die Bybel 'n doodgewone menslike boek is wat deur 
doodgewone mense in spesifieke omstandighede geskryf is. Voorts dat kerklike belydenisse en leerstellings menslike konstrukte is en nie as ewige waarhede voorgehou kan word nie. Ook hierdie dokumente en leerstellings het in bepaalde omstandighede tot stand gekom. Die oortuiging dat Jesus ter wille van mense en hul verlossing aan ' $n$ kruis moes sterf, sal agtergelaat moet word. So ook die idee dat hy binnekort weer gaan kom om finaal met dood en lyding af te rekening en 'n nuwe skepping daar te stel. Die mensdom is nie op pad na 'n nuwe hemel en 'n nuwe aarde nie, maar veel eerder na ' $n$ verwoeste en lewelose aarde indien ons nie ons lewenswyses radikaal verander nie.

'n Ander saak wat onder Christene se aandag gebring moet word, is dat hulle afskeid sal moet neem van die teïstiese idee van God - meer spesifiek die monoteïstiese idee. Jesus het nie 'n hemelse bestaan gevoer voor hy op aarde gebore was nie. Hy is soos alle mense deur ' $n$ man en 'n vrou verwek. 'n Manlike sperm het ' $n$ vroulike eiersel bevrug. As hy nie só verwek is nie, was hy nie deel van die mensspesie homo sapiens nie. Verder het hy nie gesterf onder God die Vader se toorn nie, maar onder die toorn van die Romeinse owerhede in Palestina. Hulle het sy boodskap as ' $n$ bedreiging vir die Romeinse vrede in Palestina beskou en daarom is hy, soos alle ander politieke rebelle in daardie jare, gekruisig (Horsley 2011:179-204). Die historiese Jesusnavorsing kan ons hier help om hom en sy boodskap beter te verstaan en dit ook vrugbaar van toepassing te maak in die gesprekke oor die ekologiese krisis. Jesus se boodskap was polities van aard (Horsley 2003). Hy het die koninkryk van God teenoor die koninkryk van die Romeine (ofte wel, die Romeinse Imperium) gestel en hom vir 'n billiker en meer regverdige ekonomiese en politieke bestel in Palestina beywer. Die 'groenes' in die huidige samelewing opponeer dikwels die imperiale ekonomiese en politieke magte van ons dag en daarom word hul optrede en hul boodskap (soos Jesus s'n destyds) verdag gemaak. Dis aan hierdie mense se kant dat Christene vandag moet staan. Jörg Zink (1997:58) se uitspraak ' $[a]$ theology which knows nothing but the lonely family history or family tragedy between God and humankind is a thing of the past' behoort na regte 'n banieropskrif by die nuwe verhaal te wees.

In die besinning oor 'n nuwe verhaal, sal Christene die feit dat hul godsdiens sy oorsprong as staatsgodsdiens van die Romeinse ryk gehad het, daadwerklik moet konfronteer. Christene het hulle sedert die tyd van keiser Theodosius nog altyd aan die kant van die magtiges en vermoëndes geskaar. Dit geld nie net Katolieke Christene nie, maar ook Protestantse Christene. Die Protestantse Hervorming kon slegs slaag omdat die Duitse prinse die nuwe beweging gesteun het, daarom het Martin Luther (1483-1546) dan ook die Boere-opstand van sy dag veroordeel. Op dié manier kon hy sy lojaliteit teenoor die regeerders illustreer en op hul steun reken (vgl. Bakhuizen van den Brink \& Dankbaar 1967:48-49).

'n Laaste saak wat in die verhaal ter sprake sal moet kom, is die feit dat die Christelike godsdiens hoogstens 2000 jaar oud is. Indien ons dit verreken teen die agtergrond van die verskyning van die mensspesie homo sapiens wat hoogstens 200000 jaar oud is (Silvertown 2008:154), beteken dit dat die Christelike geloof slegs maar vir 'n honderdste deel van die tyd wat ons spesie bestaan, deur mense aangehang is. Die ontwikkeling en groei van die Christelike godsdienste sal in perspektief geplaas moet word ten einde Christene daarvan bewus te maak dat hulle godsdiens ook 'n ontwikkelingsgeskiedenis deurloop het en dat meer resente kennis vereis dat ons nuut oor die verskynsel van godsdienste sal moet nadink. Die feit dat ander beskawings en kulture ander gode aangehang het, vertel eerder die verhaal dat godsdienste 'n integrale deel van mens-wees is en dat godsdiens self waarskynlik saamhang met hoe ons breine funksioneer (Lewis-Williams 2010), maar ons hoef nie meer aan die drang om gode te skep, uitdrukking te gee nie. Ons moet liewer poog om die bestaande godsdienste te omvorm tot hulpmiddels om die ekologiese krisis waarin ons onsself gestort het, te bowe te kom en om te aanvaar dat ons deel is van alles wat op aarde leef. Daar is geen ander woonplek vir ons as die aarde nie en daar is geen verlossergod wat ons uit ons ellende kan en gaan red nie.

\section{Erkenning}

Die navorsing is finansieel ondersteun deur 'n NRF-toekenning.

\section{Mededingende belange}

Die outeur verklaar hiermee dat hy geen finansiële of persoonlike verbintenis het met enige party wat hom nadelig of voordelig kon beïnvloed het in die skryf van hierdie artikel nie.

\section{Literatuurverwysings}

Asher, R.J., 2012, Evolution and belief: Confessions of a religious paleontologist, Cambridge University Press, Cambridge, UK. http://dx.doi.org/10.1017/ CB09781139022521

Ayala, F.J., 2006, Darwin and intelligent design, Fortress, Minneapolis, MN.

Bakhuizen van den Brink, J.N. \& Dankbaar, W.F., 1967, Handboek der kerkgeschiedenis, Derde Deel: Reformatie en contra-reformatie, Bart Bekker, Den Haag.

Barr, J., 1977, Fundamentalism, SCM, London.

Barr, J., 2013, 'Why the world was created in 4004 BC: Archbishop Ussher and Biblical chronology', in J. Barton (ed.), Bible and interpretation: The collected essays of James Barr, Volume II: Biblical studies, pp. 375-397, Oxford University Press, Oxford.

Beeson, T., 1999, Rebels and reformers: Christian renewal in the twentieth century, SCM, London.

Caldicott, H., 2009, If you love this planet: A plan to save the earth, Norton, New York, NY.

Conradie, E.M., 2006, Waar op dees aarde vind mens God? Op soek na 'n aardse spiritualiteit, Lux Verbi.BM, Wellington.

Conradie, E.M., 2011, Christianity and earthkeeping: In search of an inspiring vision, Sun Press, Stellenbosch.

Conradie, E.M., 2013, 'Contemporary challenges to Christian ecotheology: Some reflections on the state of the debate after five decades,' Journal of Theology for Southern Africa 147, 106-123.

Cupitt, D., 2001, Reforming Christianity, Polebridge, Santa Rosa, CA.

Cupitt, D., 2006, Radical theology: Selected essays, Polebridge, Santa Rosa, CA.

Cupitt, D., 2008, Above us only sky: The religion of ordinary life, Polebridge, Santa Rosa, CA.

Darwin, C., 1952, The origin of species by means of natural selection, or the preservation of favoured races in the struggle for life \& The descent of man and selection in relation to sex, William Benton, Chicago, IL. (Book 49 in the series Great books of the Western world). 
DeConick, A.P., 2013, Holy misogyny: Why sex and gender conflicts in the early church still matter, Bloomsbury, London.

Degenaar, J.J., 1965, Evolusie en Christendom: 'n Opstel oor Teilhard de Chardin, Simondium-uitgewers, Kaapstad.

Durand, J.J.F., 2013, Evolusie, wetenskap en geloof: 'n Biografiese inleiding tot die denke van Teilhard de Chardin, Bybel-Media, Wellington.

Eloff, J.N., 1975, 'Die dilemma van die modern Christenbioloog', Intreerede, Universiteit van die Oranje-Vrystaat, Bloemfontein, 06 Mei.

Fredriksen, P., 2012, Sin: The early history of an idea, Princeton University Press, Princeton, NJ.

Geering, L., 2001, 'Saving the planet', in T. Wallace (ed.), Time and tide: Sea of faith beyond the millennium, pp. 81-86, O Books, Hampshire.

Geering, L., 2002, Christianity without God, Polebridge, Santa Rosa, CA. http://dx.doi. org/10.7810/9781877242243

Geering, L., 2005, The greening of Christianity, St. Andrew's Trust, Wellington, NZ.

Geering, L., 2007, Wrestling with God: The story of my life, Imprint Academic, Exeter.

Geering, L., 2009, Coming back to earth: From gods, to God, to Gaia, Polebridge, Salem, OR.

Geering, L., 2013, From the Big Bang to God: Our awe-inspiring journey of evolution, Polebridge, Salem, OR.

Gore, A., 2006, An inconvenient truth: The planetary emergency of global warming and what we can do about it, Bloomsbury, London.

Goudie, A., 2013, The human impact on the natural environment: Past, present and future, 7th edition, Wiley-Blackwell, Chichester UK.

Gribbin, J., 2000, Stardust: The cosmic recycling of stars, planets and people, Penguin, London.

Gribbin, J. \& Gribbin, M., 2012, The reason why: The miracle of life on earth, Penguin, London.

Grigg, R., 2008, Beyond the God delusion: How radical theology harmonizes science and religion, Fortress, Minneapolis, MN.

Horsley, R.A., 2003, Jesus and empire: The kingdom of God and the new world disorder, Fortress, Minneapolis, MN.

Horsley, R.A., 2011, Jesus and the powers: Conflict, covenant, and the hope of the poor, Fortress, Minneapolis, MN

Kennedy, P., 2006, A modern introduction to theology: New questions for old beliefs, I.B. Tauris, London.

Lewis-Williams, D., 2010, Conceiving God: The cognitive origin and evolution of religion, Thames \& Hudson, London.

Lovelock, J., 1995, Gaia: A new look at life on earth, Oxford University Press, Oxford.

Luttikhuizen, G.P., 2006, De veelvormigheid van her vroegste christendom, Damon, Budel.

MacLeod, N., 2013, The great extinctions: What causes them and how they shape life, Natural History Museum, London.

Morvillo, N., 2010, Science and religion: Understanding the issues, Wiley-Blackwell, Chichester.

Mosley, M. \& Lynch, J., 2010, The story of science: Power, proof and passion, Mitchell Beazley, London.

Noll, M.A., 1991, Between faith and criticism: Evangelicals, scholarship, and the Bible, Apollos, Leicester.
Pagels, E., 1989, Adam, Eve, and the serpent: Sex and politics in early Christianity, Vintage Books, New York, NY.

Park, M.A., 2012, Exploring evolution, Vivays Publishing, s.n.

Primavesi, A., 2000, Sacred Gaia: Holistic theology and earth system science, Routledge, London. http://dx.doi.org/10.4324/9780203451786

Roldanus, J., 2006, The church in the age of Constantine: The theological challenges, Routledge, London.

Ryke, P.A.J., 1987, Evolusie, Universiteit van Potchefstroom, Potchefstroom. (Wetenskaplike Bydraes van die PU vir CHO, Reeks (6).

Silvertown, J., 2008, 99\% Ape: How evolution adds up, Natural History Museum, London.

Skinner, B.J. \& Murck, B.W., 2011, The blue planet: An introduction to earth system science, 3rd edn., John Wiley \& Sons, Hoboken, NJ.

Spangenberg, I.J.J., 1994, 'Paradigmaveranderinge in die Bybelwetenskappe: 'n Bydrae tot die gesprek tussen die Bybelwetenskappe en Sistematiese Teologie', Religion \& Theology 1, 144-184. http://dx.doi.org/10.1163/157430194X00141

Spangenberg, I.J.J., 2007, 'Can a major religion change? Reading Genesis 1-3 in the twenty-first century', Verbum et Ecclesia 28, 259-279. http://dx.doi.org/10.4102/ ve.v28i1.107

Spangenberg, I.J.J., 2009a, 'Darwin, die Bybel en die sondeval', Beeld By, 07 Februarie, bestig by http://152.111.1.88/argief/berigte/beeld/2009/02/17/ BJ/14/beeldrepliek.htm

Spangenberg, I.J.J., 2009b, 'The doctrines of original sin and the virgin birth: divine revelation or human construct?' Verbum et Ecclesia 30, 221-242. http://dx.doi. org/10.4102/ve.v30i1.71

Spangenberg, I.J.J., 2009c, 'Yahwism, Judaism and Christianity: religions do evolve!', in C.W. du Toit (ed.), The evolutionary roots of religion: cultivate, mutate or eliminate?, pp. 119-143, Unisa, Pretoria.

Spangenberg, I.J.J., 2011, 'Opstandingsverhale en opstandingsdogma', HTS Teologiese Studies/Theological Studies 67(1), Art. \#874, 8 pages. http://dx.doi.org/10.4102/ hts.v67i1.874

Spangenberg, I.J.J., 2013, 'Die tradisionele Christelike godsdiens en teologie in die greep van ' $n$ verouderde paradigma: Diagnose en prognose', in LitNet Akademies (Godsdienswetenskappe), besigtig by http://www.litn/et.co.za/Article/dietradisionele-christelike-godsdiens-en-teologie-in-die-greep-van-n-verouderdeparadigma

Spangenberg, I.J.J., 2014, 'Is versoening tussen natuurwetenskap en Christelike geloof moontlik?', Lesing gelewer tydens 'n Midrand-byeenkoms van die Nuwe Hervorming Netwerk, 02 Februarie, besigtig by http://www.nuwe-hervorming. co.za/argief/is-versoening-tussen-natuurwetenskap-en-die-christelike-geloofmoontlik-deur-sakkie-spangenberg/

Stewart-Williams, S., 2010, Darwin, God and the meaning of life: How evolutionary theory undermines everything you thought you knew, Cambridge University Press, Cambridge. http://dx.doi.org/10.1017/CBO9780511778827

Theron, P.F., 1978, Die ekklesia as kosmies-eskatologiese teken, N.G. Kerkboekhandel, Pretoria. (Raad vir Geesteswetenskaplike Navorsing, Publikasiereeks 66).

Thomson, K. 2005, Before Darwin: Reconciling God and nature, Yale University Press, New Haven, CT.

Weinert, F., 2009, Copernicus, Darwin, \& Freud: Revolutions in the history and philosophy of science, Wiley-Blackwell, Chichester.

White, L., 1967, 'The historical roots of our ecological crisis', Science 155, March, 1203-1207. http://dx.doi.org/10.1126/science.155.3767.1203

Zink, J., 1997, 'Jörg Zink', in J. Moltmann (ed.), How I have changed: Reflections on thirty years of theology, pp. 55-64, SCM, London. 